\title{
EVALUATING DISTANCE EDUCATION IN SERBIA DURING THE COVID-19 PANDEMIC
}

\author{
Suzana V. Marković Krstić, Lela R. Milošević Radulović \\ University of Niš, Republic of Serbia \\ E-mail: suzana.markovic.krstic@filfak.ni.ac.rs, \\ lela.milosevic.radulovic@filfak.ni.ac.rs
}

\begin{abstract}
Education is a significant factor which contributes to overcoming social, economic, health, ecological and other challenges. During a pandemic, formal education adapts to ongoing circumstances, and the learning-teaching process transitions to distance education. A study of the advantages and disadvantages of the realization of certain modalities of distance education is significant as it contributes to the improvement of its quality. The aim was to determine how the citizens of Serbia evaluated the quality of distance education during the COVID-19 pandemic. The research questions focused on how they evaluated: distance education based on modality (via Radio Television of Serbia, Google Classroom, Google Meet, Zoom, Viber groups, WhatsApp), the level of involvement of the learners/students during distance learning classes, the quality and extent of their acquired knowledge, and the level of skills that teachers need to effectively teach in distance education. The study presents the results of a survey carried out in 2020 on a sample of 602 adult Serbian citizens. The results confirm the initial hypothesis that certain modalities of distance education received a highly positive evaluation (Google Classroom, Google Meet, Zoom), and that teachers, learners/students, and other citizens provided statistically significant different evaluations of their quality (classes for primary and secondary school students broadcast on the Radio Television of Serbia; classes via Viber groups, on WhatsApp). Citizens feel that distance education enables efficient learning-teaching during the pandemic, confirming the importance of modern technologies for the learning-teaching process in Serbia, and the need for their continued intense development and application in education.
\end{abstract}

Keywords: learners/students, distance education, Serbia, teachers'skills, the COVID-19 pandemic

\section{Introduction}

Globalization as a planetary process which creates a network of technological, economic, political and cultural connections also brings an increasingly greater mutual dependence in contemporary society (Gidens, 2003; Held, 1999, 2003; Wallernstein, 2000). It essentially changes the way an individual thinks about themselves and their relationship with other people (Gidens, 2003, p. 66). Considering that communication is increasingly more often taking place by means of new technologies (the internet, mobile phones), the implications of using these technologies are very complex. Their development has enabled us to connect with the entire world (in terms of work, education, entertainment, etc.), while at the same time, any new communication system radically transforms space and time, the fundamental dimensions of human life.

The COVID-19 pandemic introduced far-reaching changes into our social life and led to consequences which are difficult to foresee and control. Considering that the risk for human health increased, the number of attempts of numerous researchers and scientists to study the etiology and epidemiology of this virus also increased. This decreased the possibility of the virus spreading and had an impact on the treatment of those who contracted it. Beck has pointed 
Suzana V. MARKOVIĆ KRSTIĆ, Lela R. MILOŠEVIĆ RADULOVIĆ. Evaluating distance education in Serbia during the Covid-19 pandemic

PROBLEMS

OF EDUCATION IN THE $21^{\text {st }}$ CENTURY Vol. 79, No. 3, 2021

468

out that living at a time when numerous values are clashing with our contemporary way of life is accompanied by many risks. Life in a "risk society" (Beck, 1992) in the era of globalization requires an individual and society to react adequately and make decisions regarding the causes and effects of certain risks. A risk society is not limited solely to the risks to one's health and the environment. It includes an entire range of mutually connected changes in contemporary social life: changes in work patterns, lack of job security, lower impact of tradition and customs related to self-identity, the erosion of traditional forms of the family, the democratization of personal relationships. In addition, making decisions regarding education is also risky, since it is very difficult to predict which skills and abilities will be considered vital in an economy and society which are rapidly changing (Gidens, 2003). Life at a time of globalization and informatization presents man with a new set of requirements and new tasks which also need to be addressed in the education system (Marković, 2008). In such altered social circumstances, this system is presented with a set of demands, including the need for its adaptation to changes in the sphere of work and employment.

During a pandemic, global social processes acquire their own specific manifestation in all spheres of social life, and especially in the sphere of education. The corona virus pandemic posed numerous challenges to theoretical and practical approaches, clearly pointing out the connection between the social context, the quality of education, and the modality of the practical realization of curricula (Defining quality in education, 2000). The modification and adaptation of the learning-teaching process during the pandemic requires new practical solutions. We can identify three basic challenges to distance education during the pandemic. The first refers to technical requirements, which can be overcome by purchasing better technical equipment, provided one is financially able to do so. The second refers to the inability of "direct transfer" from the physical to the virtual classroom due to a lack of contact with other learners/students and teachers, which is very complex and difficult to overcome. The third requires the involvement of the learners/students themselves, as well as their teachers, to find the best possible method to acquire and understand the teaching material in the digital environment. Ćamilović has pointed out that the quality of this kind of work does not depend solely on technical equipment, but also on the involvement of the teachers and learners/students. As a result, offering appropriate training to both participants in the process is very important as it is providing technical support during their work (see Ćamilović, 2012). In the era of digitalization, distance education is seen as one of the possible solutions to the problem of ensuring that both learners and students remain healthy on the one hand (physical distance), and that the curricula on all levels of education is realized successfully (the quality of education) on the other. This provides the successful adaptation of individuals to ongoing circumstances and is an adequate response to the challenges of a risk society in the form of developing appropriate skills and competences.

The Government of the Republic of Serbia, due to the epidemiological situation (COVID-19), passed the Decision on suspension of teaching in higher education institutions and primary and secondary schools, and the regular work of institutions for pre-school education ${ }^{1}$. Under such circumstances, the Ministry of Education, Science and Technological Development has since March 17, 2020 organized distance education and made an Operational plan for the continuation of schools' work in difficult conditions. Priority in distance education for primary and secondary schools was given to program content pertaining to general education courses, and courses with a greater number of classes. The Ministry of Education, Science and Technological Development passed the Rulebook on the requirements for achieving quality and the manner of quality assurance and evaluation of distance learning in primary schools (in Serbian: Pravilnik o bližim uslovima za ostvarivanje i način osiguranja kvaliteta $i$ vrednovanje nastave na daljinu u osnovnoj školi) ${ }^{2}$. Classes in the new schoolyear in schools/at universities took the form of distance learning (combined learning-teaching) for both primary and secondary school students, as well as university students. 
Accordingly, the study analyzes and interprets the results of the empirical study "Changes in the social life of the citizens of Serbia during the pandemic" (in Serbian: Promene u društvenom životu građana Srbije u doba pandemije), which refers to distance education and its modalities, as well as the level of participation and involvement of the learners/students in distance learning, the quality and extent of their acquired knowledge, and the level of skills that teachers need to effectively teach in distance education. Theoretical approaches and previous research carried out locally and abroad (Barrett, 2020; Ćamilović, 2012; Stepanović, 2020; Stojanović, 2020) provided the basis for the interpretation and comparison of the results which indicate differences, but also similar experiences when it comes to the quality of education and distance education during the pandemic. The results of previous studies refer to the advantages and disadvantages of distance education as seen by teachers, teaching associates/assistants, school managers, and parents. The current study began with the aim of analyzing the quality of specific modalities of this type of education based on noted shortcomings in its realization. The evaluation was provided by the participants in the educational process (the teachers/students) and other citizens of Serbia.

\section{Research Questions}

The main research question refers to how adult citizens of Serbia evaluated the quality of distance education in Serbia during the pandemic. This research question includes the responses to the following questions:

1. What were the results of the evaluation of the quality of distance education provided for primary and secondary school students, broadcast on Radio Television of Serbia?

2. What were the results of the evaluation of the quality of online education taking place on platforms such as Google Classroom, Google Meet, Zoom and the like?

3. What were the results of the evaluation of the quality of online education taking place via Viber groups and on WhatsApp?

4. What were the results of the evaluation of the level of participation and involvement of the learners/students in distance learning classes?

5. What were the results of the evaluation of the quality and extent of the knowledge acquired by learners/students during their distance learning classes?

6. What were the results of the evaluation of the level of skills that teachers need to effectively teach in distance education?

\section{Research Methodology}

\section{General Background}

In accordance with the epidemiological situation in Serbia, classes organized on all levels of education have temporarily been suspended with the aim of preserving and protecting the health of all citizens. After a state of emergency was declared in Serbia (March 16, 2020), distance education began on March 17, 2020. For primary and secondary school students, the broadcast of educational content began on the channels of the Radio Television of Serbia (RTS), while university students began online classes on various platforms (Google Meet, Google Classroom, Zoom), and through various groups (Viber, WhatsApp) etc. At the same time, workshops were organized for both students and teachers, and technical support was provided for universities.

The Ministry of Education, Science and Technological Development of the Republic of Serbia, in cooperation with RTS, organized the recording and broadcasting of educational content meant for distance education via the RTS 2, RTS 3 and RTS Planeta channels (all 
Suzana V. MARKOVIĆ KRSTIĆ, Lela R. MILOŠEVIĆ RADULOVIĆ. Evaluating distance education in Serbia during the Covid-19 pandemic

PROBLEMS

OF EDUCATION IN THE $21^{\text {st }}$ CENTURY Vol. 79, No. 3, 2021

470

channels with a national frequency). The educational programs which followed the curricula of selected general education courses, specially tailored to meet the needs of primary and secondary school students and in accordance with the annual work plan, are broadcast daily from 8am, which is congruent with the hours when the school activities of students begin under regular circumstances. The teachers were instructed on how to record educational material in their homes, and the school principals and home-room teachers use text messages or social networking sites (Viber, Facebook, and the like) to inform their students about the programming schedule, i.e., when classes are being broadcast on RTS channels. Thus, the learning-teaching process also includes those students who do not have access to the internet. The schools regularly update their websites and set up links with notifications regarding the programming schedule for classes broadcast on RTS channels. In addition, all the lessons which are broadcast on national television are also available on the RTS website, as well as on the RTS Planeta platform, so that the students can view them even after the broadcast. All of the educational content is available via the free app "RTS Moja škola" for mobile phones and tablets. This is also helpful for the students as it makes it easier for them to follow their lessons while at home. In addition, the teachers also prepare lessons in the form of presentations which contain guidelines on how to study and send them to the learners/students via email or via social networking sites. Based on the learners/students' homework assignments, completed exercises, essays, their presentations, the feedback they give after class, and the distribution of material, the teachers monitor the progress of their students, their workload, and their motivation to learn.

The initial hypothesis was that the citizens of Serbia give a positive evaluation of distance education and that there are statistically significant differences in their evaluations depending on whether they are directly and actively (teachers and learners/students) or indirectly (parents or observers) taking part in the learning-teaching process.

\section{Sample}

The study of the evaluation of the quality of distance education is part of a more extensive empirical research "Changes in the social life of the citizens of Serbia during the pandemic". The research was carried out by a group of researchers ${ }^{3}$ of the Center for Sociological Research of the Faculty of Philosophy of Niš, in collaboration with the Sociological Society of Serbia, from April to June 2020. The research was carried out anonymously, through an online survey, and included a sample of 602 adult citizens of Serbia (the number of citizens who responded for the duration of the study), 235 of whom were active participants in the learning-teaching process (123 teachers $-20.4 \%$ and 112 learners/students - 18.6\%) and 367 of whom were other citizens $(61.0 \%)$.

Since a convenience sample was used, generalized conclusions cannot be drawn, but the research results can be a useful indicator of the quality of distance education and can be used for further research, and for planning the development and improvement of the quality of distance education. The respondents voluntarily agreed to fill out the online questionnaire, and the anonymity and confidentiality of their personal data was guaranteed.

\section{Instruments and Procedure}

The instrument was a survey questionnaire which was distributed via email and social media from various access points from April 23 to June 13, 2020. The questionnaire was designed by the researchers of the Center for Sociological Research of the Faculty of Philosophy of Niš and consisted of 52 closed and open-ended items. A set of questions was used in this study, which referred to the quality of distance education during the pandemic. The evaluations of the citizens were given on a scale of 1 to 5 (unsatisfactory - excellent). Cronbach's alpha 
Suzana V. MARKOVIĆ KRSTIĆ, Lela R. MILOŠEVIĆ RADULOVIĆ. Evaluating distance education in Serbia during the Covid-19 pandemic

coefficient was used to measure the reliability of the instruments. Its value was determined to be .90 , which indicated that the instrument was reliable for use in this study. The study was a quantitative sociological study, based on a descriptive and exploratory approach, which included the implementation of a comparative-analytical and statistical method. Spearman's rank correlation coefficient calculated for all the items mutually evaluated the reliability of the survey. It proved that the survey was reliable as its values ranged from .4 to .7, which is a medium strong correlation.

The respondents were divided into three groups: the teachers (who directly and actively took part in preparing and teaching distance classes), the learners/students ${ }^{4}$ (who were also direct participants in the learning-teaching process, during which they acquired knowledge and develop abilities), and the other citizens of Serbia (who indirectly, as parents or observers, evaluated the performance of distance education classes).

\section{Data Analysis}

In accordance with the aim of the research, suitable statistical procedures were used to analyze the research results. The analysis included descriptive statistics and the determination of basic statistical indicators (frequency distribution and percentages). The statistical significance of the differences between certain groups was tested using the $\chi^{2}$. The data were processed through the SPSS program for statistical data analysis.

\section{Research Results}

How the citizens of Serbia evaluated the quality of distance education during the pandemic was viewed through six indicators: 1) the evaluation of distance education meant for primary and secondary school students, broadcast on RTS; 2) the evaluation of online education via the Google Classroom, Google Meet, Zoom platforms; 3) the evaluation of the quality of online education via groups on Viber, WhatsApp; 4) the evaluation of the level of participation and involvement of the students in distance education; 5) the evaluation of the quality and extent of knowledge acquired by the students during their distance learning classes; 6) the evaluation of the quality of work of the teachers and the level of skills that teachers need to effectively teach in distance education during the pandemic. Table 1 shows the research results which refer to the evaluation of the quality of distance education in Serbia during the pandemic.

$\mid$\begin{tabular}{l} 
PROBLEMS \\
OF EDUCATION \\
IN THE 21 $1^{\text {st }}$ CENTURY \\
Vol. 79, No. 3, 2021 \\
\hline 471
\end{tabular} 
Suzana V. MARKOVIĆ KRSTIĆ, Lela R. MILOŠEVIĆ RADULOVIĆ. Evaluating distance education in Serbia during the Covid-19 pandemic

PROBLEMS

OF EDUCATION

IN THE $21^{\text {st }}$ CENTURY

Vol. 79 , No. 3, 202

Table 1

An Evaluation of the Quality of Distance Education: The Citizens of the Republic of Serbia (\%)

\begin{tabular}{lllllll}
\hline Evaluation of quality & Unsatisfactory & Sufficient & Good & Very good & Excellent & Total $^{5}$ \\
\hline $\begin{array}{l}\text { The quality of distance education } \\
\text { meant for primary and secondary } \\
\text { school students, broadcast on RTS }\end{array}$ & 7.2 & 12.3 & 27.5 & 33.2 & 19.8 & 100.0 \\
\hline $\begin{array}{l}\text { The quality of online education via } \\
\text { the Google Classroom, Google Meet, } \\
\text { Zoom platforms }\end{array}$ & 5.4 & 9.7 & 25.1 & 36.2 & 23.6 & 100.0 \\
\hline $\begin{array}{l}\text { The quality of online education via } \\
\text { groups on Viber, WhatsApp }\end{array}$ & 9.3 & 12.3 & 29.8 & 30.6 & 18.1 & 100.0 \\
\hline $\begin{array}{l}\text { The level of participation and } \\
\text { involvement of the students in } \\
\text { distance education }\end{array}$ & 5.6 & 15.4 & 28.3 & 30.8 & 19.9 & 100.0 \\
\hline $\begin{array}{l}\text { The quality and extent of knowledge } \\
\text { acquired by the students during their } \\
\text { distance learning classes }\end{array}$ & 8.8 & 20.1 & 34.8 & 25.8 & 10.5 & 100.0 \\
\hline $\begin{array}{l}\text { The level of skills that teachers } \\
\text { need to effectively teach in distance } \\
\text { education }\end{array}$ & 6.2 & 1.49 & 25.8 & 34.2 & 18.9 & 100.0 \\
\hline
\end{tabular}

The research results indicated a predominantly positive evaluation of distance education, the participation and involvement of students during distance education, and the level of skills that teachers need to effectively teach in distance education. In general, the grade 4 (very good) was most prevalent, and it was most frequently $(36.2 \%)$ awarded to the following modality the quality of online education via the Google Classroom, Google Meet, Zoom platforms. This modality also received the highest mark (23.6\%) more often than the others. On the other hand, the lowest overall score compared to the other modalities was determined for the quality of online education via groups on Viber, WhatsApp (9.3\%).

In order to compare the research results and the perceived differences in the perceptions and evaluations of certain dimensions of the quality of distance education made by the direct participants in the learning-teaching process (the teachers and the students), and the other citizens of the Republic of Serbia included in the study, Tables 2 and 3 present the results of their evaluation of the quality of distance education. 
Suzana V. MARKOVIĆ KRSTIĆ, Lela R. MILOŠEVIĆ RADULOVIĆ. Evaluating distance education in Serbia during the Covid-19 pandemic

\section{Table 2}

An Evaluation of the Quality of Distance Education: The Teachers (\%)

\begin{tabular}{lcccccc}
\hline Evaluation of quality & Unsatisfactory & Sufficient & Good & Very good & Excellent & Total \\
\hline $\begin{array}{l}\text { The quality of distance education } \\
\text { meant for primary and secondary } \\
\text { school students, broadcast on RTS }\end{array}$ & 2.0 & 10.2 & 31.6 & 30.6 & 25.5 & 100.0 \\
\hline $\begin{array}{l}\text { The quality of online education via } \\
\text { the Google Classroom, Google } \\
\text { Meet, Zoom platforms }\end{array}$ & 2.2 & 7.6 & 30.4 & 28.3 & 31.5 & 100.0 \\
\hline $\begin{array}{l}\text { The quality of online education via } \\
\text { groups on Viber, WhatsApp }\end{array}$ & 6.5 & 12.0 & 28.3 & 25.0 & 28.3 & 100.0 \\
\hline $\begin{array}{l}\text { The level of participation and } \\
\text { involvement of the students in } \\
\text { distance education }\end{array}$ & 4.2 & 11.5 & 29.2 & 36.5 & 18.8 & 100.0 \\
\hline $\begin{array}{l}\text { The quality and extent of knowledge } \\
\text { acquired by the students during their } \\
\text { distance learning classes }\end{array}$ & 5.3 & 19.1 & 42.6 & 23.4 & 9.6 & 100.0 \\
\hline $\begin{array}{l}\text { The level of skills that teachers } \\
\text { need to effectively teach in distance } \\
\text { education }\end{array}$ & 3.1 & 9.4 & 35.4 & 34.4 & 17.7 & 100.0 \\
\hline
\end{tabular}

The analysis of the research results which refer to how the teachers evaluated certain dimensions of the quality of distance education indicated that the positive evaluations predominantly ranged from "good" to "excellent" (3-5). The highest scores were determined for the quality of online education carried out via the Google Classroom, Google Meet, Zoom platforms (31.5\%), and the quality of online education carried out via groups on Viber, WhatsApp (23.8\%). What was also interesting was the evaluation of the work of the teachers themselves, that is, the evaluation of the level of skills that teachers need to effectively teach in distance education. Even though it was expected that they would evaluate their work with high marks, the most frequently occurring grade was still 3 (35.4\%).

When it comes to how the students themselves evaluated the quality of distance education (Table 3), the analysis of the results indicated the dominant prevalence of "good" and "very good" (grades 3 and 4). The highest score was determined for online education via the Google Classroom, Google Meet, Zoom platforms (27.8\% grade 5 and $37.1 \%$ grade 4$)$. 
Suzana V. MARKOVIĆ KRSTIĆ, Lela R. MILOŠEVIĆ RADULOVIĆ. Evaluating distance education in Serbia during the Covid-19 pandemic

PROBLEMS

OF EDUCATION IN THE $21^{\text {st }}$ CENTURY Vol. 79 , No. 3, 202

Table 3

An Evaluation of the Quality of Distance Education: The Students (\%)

\begin{tabular}{lllllll}
\hline Evaluation of quality & Unsatisfactory & Sufficient & Good & Very good & Excellent & Total \\
\hline $\begin{array}{l}\text { The quality of distance education } \\
\text { meant for primary and secondary } \\
\text { school students, broadcast on RTS }\end{array}$ & 12.4 & 18.0 & 29.2 & 24.7 & 15.7 & 100.0 \\
\hline $\begin{array}{l}\text { The quality of online education via } \\
\text { the Google Classroom, Google Meet, } \\
\text { Zoom platforms }\end{array}$ & 7.2 & 8.2 & 19.6 & 37.1 & 27.8 & 100.0 \\
\hline $\begin{array}{l}\text { The quality of online education via } \\
\text { groups on Viber, WhatsApp }\end{array}$ & 16.5 & 17.6 & 27.1 & 25.9 & 12.9 & 100.0 \\
\hline $\begin{array}{l}\text { The level of participation and } \\
\text { involvement of the students in } \\
\text { distance education }\end{array}$ & 8.2 & 19.4 & 25.5 & 25.5 & 21.4 & 100.0 \\
\hline $\begin{array}{l}\text { The quality and extent of knowledge } \\
\text { acquired by the students during their } \\
\text { distance learning classes }\end{array}$ & 13.4 & 19.6 & 32.0 & 21.6 & 13.4 & 100.0 \\
\hline $\begin{array}{l}\text { The level of skills that teachers } \\
\text { need to effectively teach in distance } \\
\text { education }\end{array}$ & 10.2 & 16.3 & 14.3 & 31.6 & 27.6 & 100.0 \\
\hline
\end{tabular}

Following the analysis and comparison of the research results, the highest scores were determined for online classes via the Google Classroom, Google Meet, Zoom platforms. In this case, high grades were given by the students in particular (as many as $64.9 \%$ of the students awarded it grades 4 and 5). On the other hand, the other citizens awarded the quality of online education carried out via groups on Viber, WhatsApp the lowest grades.

\section{Differences in the Perception of the Quality of Distance Education Among the Teachers, the Students, and the Other Citizens of Serbia}

The statistical analysis $\left(\chi^{2}\right)$ of the differences in how the teachers, the students, and the other citizens of Serbia evaluated the quality of distance education for primary and secondary school students broadcast on RTS (Radio Television of Serbia) indicated statistically significant differences among the three groups $\left(\chi^{2}=17.24, d f=8, p=.03\right)$. The teachers mostly evaluated the lessons broadcast on RTS with 3 (31.6\%), as did the students $(29.2 \%)$, while among the other citizens of Serbia the dominant grade was 4 (38.1\%). At the same time, the teachers, compared to the other respondents, awarded the quality of lessons broadcast on RTS with the highest grades. That is, $25.5 \%$ of the teachers considered this type of teaching to be excellent (Figure 1). 
Suzana V. MARKOVIĆ KRSTIĆ, Lela R. MILOŠEVIĆ RADULOVIĆ. Evaluating distance education in Serbia during the Covid-19 pandemic

\section{Figure 1}

An Evaluation of the Quality of Lessons Being Broadcast on RTS: The Teachers, the PROBLEMS OF EDUCATION IN THE $21^{\text {st }}$ CENTURY Vol. 79 , No. 3, 2021 Students, and the Other Citizens of Serbia (\%)

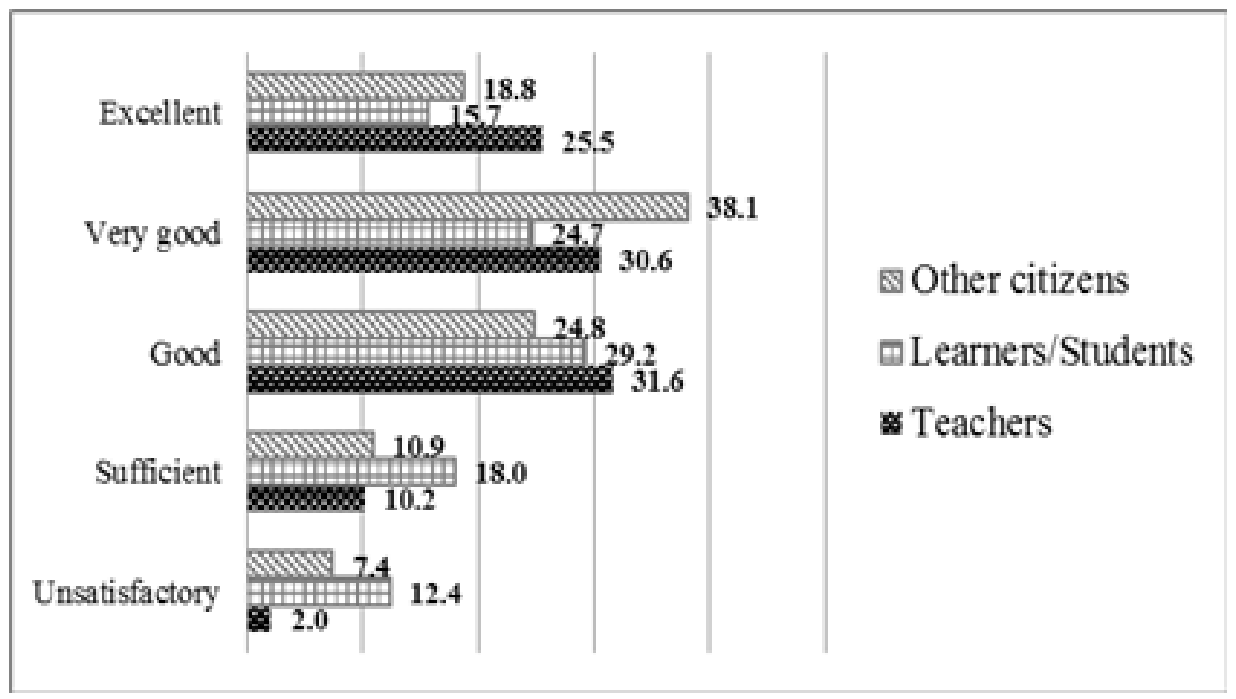

The research results which refer to the evaluation of the quality of online education via the Google Classroom, Google Meet, Zoom platforms (Figure 2) indicated that this modality was awarded the highest grades by all the respondents included in the study (the teachers, the students, and the other citizens of Serbia). The results of the Chi-square analysis indicated that there were no statistically significant differences in the evaluation of the quality of this modality of teaching among the three groups.

\section{Figure 2}

An Evaluation of the Quality of Lessons via the Google Classroom, Google Meet, Zoom Platforms: The Teachers, the Students, and the Other Citizens of Serbia (\%)

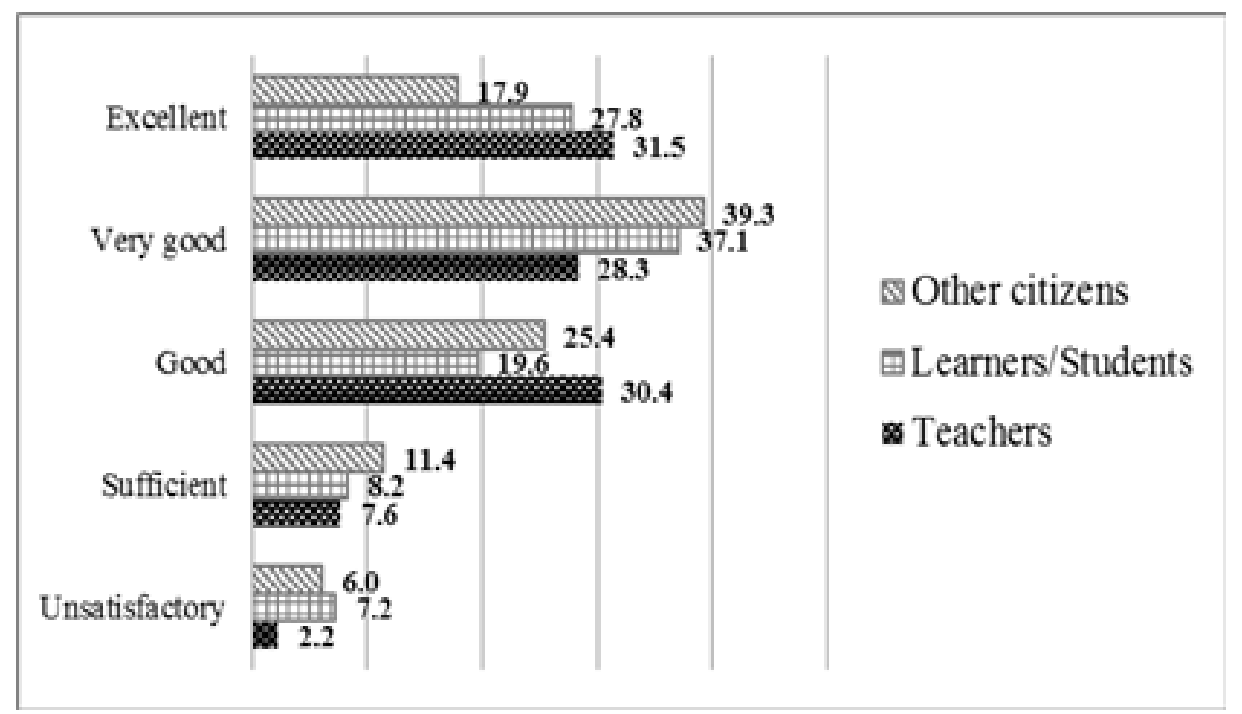


Suzana V. MARKOVIĆ KRSTIĆ, Lela R. MILOŠEVIĆ RADULOVIĆ. Evaluating distance education in Serbia during the Covid-19 pandemic

PROBLEMS

OF EDUCATION IN THE $21^{\text {st }}$ CENTURY Vol. 79, No. 3, 2021

When it comes to how the teachers, the students, and the other citizens of Serbia evaluated online education via groups on Viber, WhatsApp, a statistically significant difference was noted (Figure 3). A comparison of the empirical findings indicated that the highest grades for this kind of learning-teaching were awarded by the teachers $(28.3 \%)$, while the key actors in the learning-teaching process, the students, mostly awarded it with the grade $3(27.1 \%)$. The other citizens of Serbia mostly awarded this modality of the learning-teaching process with the grade $4(35.2 \%)$. The results of the Chi-square test $\left(\chi^{2}=19.58, d f=8, p=.01\right)$ confirmed that there were statistically significant differences in the evaluation of the quality of this type of online education.

Figure 3

An Evaluation of the Quality of the Lessons via Groups on Viber, WhatsApp: The Teachers, the Students, and the Other Citizens of Serbia (\%)

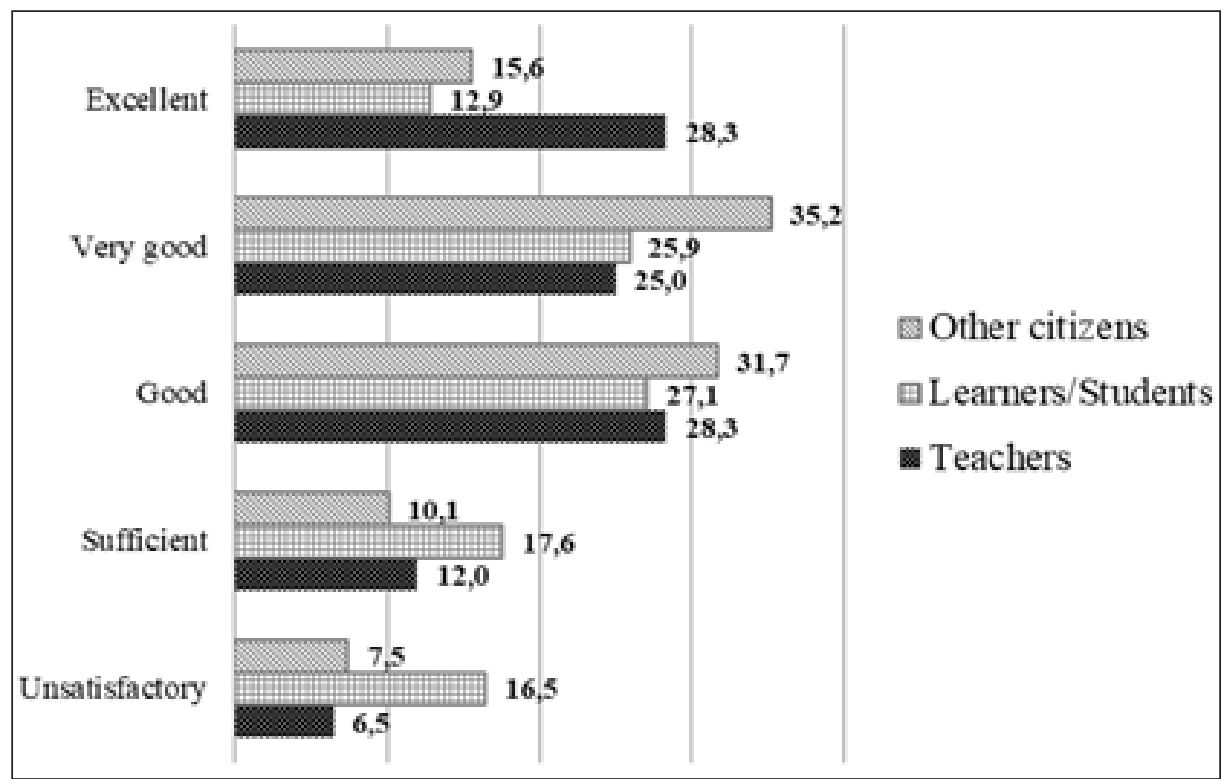

A special segment in the research refers to how the other citizens of Serbia evaluated the levels of participation and involvement of the students during distance learning classes. The empirical findings indicated that there were no statistically significant differences among the respondents in their evaluations (the most frequently awarded grade was 4). In addition, the analysis of the research results regarding the quality and extent of the knowledge acquired by the students during distance education indicated that there were no statistically significant differences among the teachers, the students, and the other citizens of Serbia (the most frequently awarded grade was 3 ).

Statistically significant differences were noted for how the teachers, the students, and the other citizens of Serbia evaluated the level of skills that teachers need to effectively teach in distance education $\left(\chi^{2}=20.87, d f=8, p=.01\right)$. Even though the dominant grade given by the students was $4(31.6 \%)$, as was the case with the other citizens of Serbia (35.4\%), the teachers themselves, whose skills were being evaluated, were more critical in their evaluation than the other respondents, and most frequently awarded their work with the grade $3(35.4 \%)$ (Figure 4). 
Suzana V. MARKOVIĆ KRSTIĆ, Lela R. MILOŠEVIĆ RADULOVIĆ. Evaluating distance education in Serbia during the Covid-19 pandemic

\section{Figure 4}

An Evaluation of the Quality of the Level of Skills That Teachers Need to Effectively Teach in Distance Education: The Teachers, the Students, and the Other Citizens of Serbia (\%)

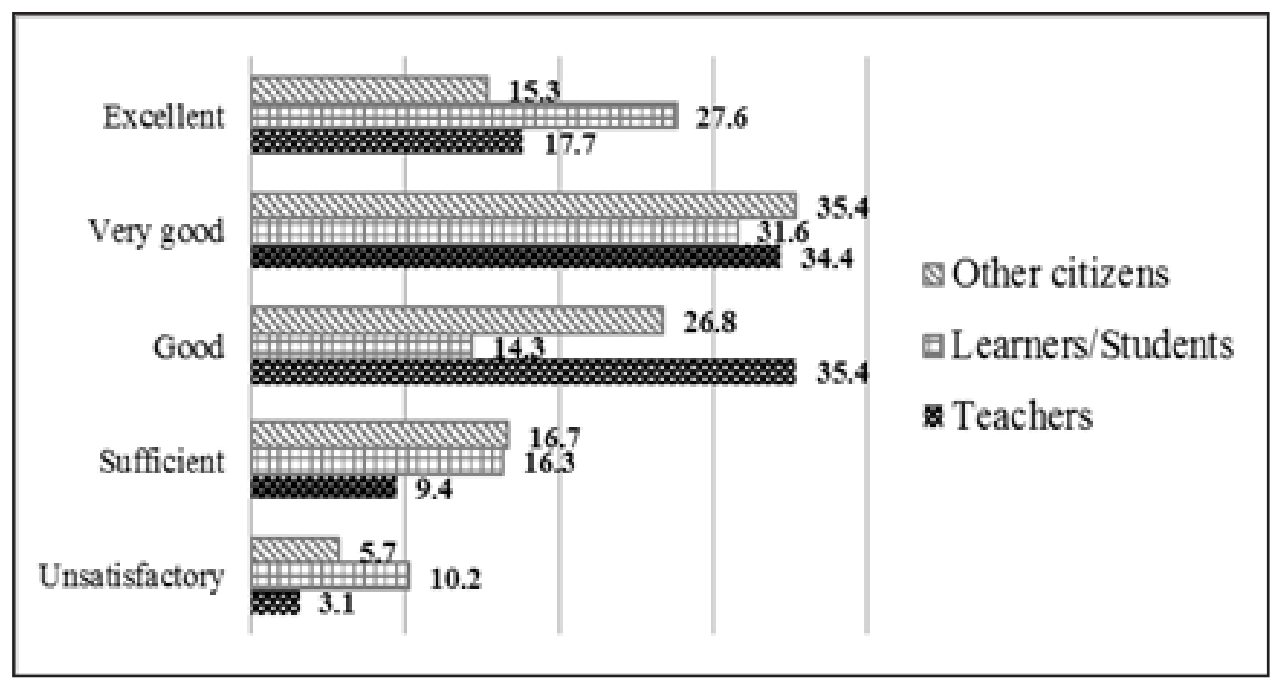

\section{Discussion}

The research results regarding the perceptions on and evaluation of distance education made by the citizens of Serbia, that is, the teachers and the students (direct participants in the learning-teaching process), and the other citizens of Serbia (parents and observers indirectly monitoring distance learning classes) confirmed the initial hypothesis on the existence of significant differences in their evaluations of the modalities of distance education, and the evaluation of the level of skills that teachers need to effectively teach in distance education.

Positive evaluations of the quality of distance learning classes broadcast via RTS, as well as differences regarding how the teachers and the students on the one hand, and the other citizens on the other, evaluated distance education can in part be explained by how quickly the transition was made to distance education following the declaration of the state of emergency. They can also be explained by the availability of this type of education to both the participants in the learning-teaching process (based on ownership of a television set), and those not directly participating in it. This has made it possible to overcome the issue of social inequality among the students in terms of access to certain resources and to contemporary educational technology. In addition, the very few requirements regarding the digital competences of the teachers and learners render the classes broadcast via RTS suitable for all the participants in the learningteaching process. However, the results of previous studies (Stepanović, 2018) have also indicated certain shortcomings of this type of education. These include a focus on average learners in the learning-teaching process, the inability to interact with others and receive feedback based on which the teacher could gain insight into whether the learner has understood the material in order to continue with the curriculum. The teachers are limited in their ability to work individually with students in order to adapt the material to the content that was broadcast on television, the learners are given too much material for independent work, and there is insufficient time for practice.

An explanation of the prevalence of high grades awarded to quality of education via platforms such as Google Classroom, Google Meet, Zoom is based on both the availability of these platforms for learning, and the fact that it was relatively easy to quickly organize and educate teachers and students on how to use them in class. The constant focus of the students 
Suzana V. MARKOVIĆ KRSTIĆ, Lela R. MILOŠEVIĆ RADULOVIĆ. Evaluating distance education in Serbia during the Covid-19 pandemic

PROBLEMS

OF EDUCATION IN THE $21^{\text {st }}$ CENTURY Vol. 79, No. 3, 2021

478

on the electronic media as a means of communication, leisure time entertainment, independent study, and the search for information made it possible for the students to adapt to these media and the platforms used in distance education. On the other hand, teachers successfully used the advantages offered by these media for the presentation of material in an original and contemporary way, which had a positive effect on the students and led them to actively participate in distance learning classes. These results are in line with the results of previous studies carried out in Serbia and Europe (School Education Gateway, 2020; Stojanović, 2020; Institute for the Improvement of Education of the Republic of Serbia, 2020), which have indicated that the predominant responses to questions regarding distance education during the pandemic were to a great extent identical (the implementation of this type of education, positive characteristics, and problems). Most teachers in Serbia have experience using the Google Classroom platform $(52.3 \%)$ and have pointed out the advantages of distance education in terms of efficiency, creativity when preparing for and teaching classes, flexibility, and the like. The main problems regarding distance education do not vary: the (un)availability of resources and technology to stress.

The significant differences in terms of the evaluations of online education (on Viber groups, WhatsApp) made by the direct participants in the learning-teaching process (the teachers and the students) can be explained by the different roles they have within it. The role of the teacher in this case included the preparation and distribution of material to students for independent work at home, along with guidelines on how to do the work, as well as the timely communication, and evaluation of the achieved results. This type of education is not synchronous and the students, after receiving the material and tasks for independent work, can contact their teachers for additional explanations (King et al., 2001; Kung-Ming \& KhoonSeng, 2009). This process of individual learning takes place at a pace that is either slower or quicker than that expected by the students, which can be considered one of the disadvantages of this type of education, and thus can explain the lower grades awarded for the quality of this modality of distance education by the students. Besides, additional disadvantages can also refer to the lack of supervision, and a special approach to students who are above average or below average in terms of their progress, as well as students with special needs.

The research results, which confirmed the differences in how the teachers and the students evaluated the quality of online education on Viber groups, WhatsApp, whereby the teachers evaluated this type of education with higher marks than the students did, were congruent with the "seven principles" model of online education. The basic components of the "seven principles of good practice" for online education include: 1) encouraging contact as part of the studentteacher relationship, 2) encouraging cooperation among the students, 3) encouraging active learning, 4) providing timely feedback, 5) clearly pointing out the time needed to perform a task, 6) communication at a higher level, and 7) respect of diverse talents and various types of learning. Student motivation, their involvement and intellectual commitment all depend on the quality of communication between the student and teacher, both within and outside the educational institution. Cooperation in the learning process increases participation in the learning process on the part of the students and improves the exchange of ideas (Orellana et al., 2009). In that respect, the significant differences in how the teachers and the students evaluated the quality of this type of distance education can be explained by the prominent role of the teacher as communicator and motivator in the learning-teaching process. Higher grades were awarded by the teachers than by the students for the quality of this type of education, as a result of a more positive evaluation of their active role in the process of distance education.

When it comes to how the teachers, the students, and the other citizens of Serbia evaluated the level of participation and involvement of the students in distance learning classes, no statistically significant differences were determined. The most frequently awarded grade was 4 ("very good quality"), which can also be a confirmation of the fact that the 
students were showing interest, commitment, participation, and motivation to, even in these extraordinary circumstances, complete their assignments. On the other hand, the inability to regularly attend classes in an academic setting, which also includes socializing with their peers, direct communication with their teachers during distance learning classes can in part be compensation for any activities carried out at home during distance education. In addition, most of the respondents recognized that the students were attempting to adequately respond to the challenges they find themselves facing in the pandemic caused by the corona virus through their participation in the educational process and evaluated that effort with high grades. These findings are congruent with the research of the quality of distance education carried out by the Ministry of Science and Education of the Republic of Croatia. The research results have indicated that the opinions of teachers were divided when it comes to the activities of the students during distance education and their activities in the classroom $-58 \%$ of the teachers believed that the students are more active in school, while $42 \%$ were of the opinion that they are more active during distance learning classes (Action plan for the implementation of the distance education, 2020).

The research results on how the teachers, the students, and the other citizens of Serbia evaluated the quality and extent of the knowledge acquired by the students indicated similar evaluations across all three groups. The prevalence of the grade 3 was recorded among all three groups of respondents, the teachers, the students, and the other citizens. On the other hand, the students more than everyone else gave both the lowest and highest grade (13.4\% each). This kind of evaluation of the quality and extent of acquired knowledge can in part be explained by their positive and negative experiences during distance education, and their critical relationship to and (dis)satisfaction with the achieved results in the learning-teaching process.

When it comes to the evaluation of the level of skills that teachers need to effectively teach in distance education, the research results indicated that there were statistically significant differences among the teachers, the students, and the other citizens. Even though the skills of the teachers were awarded high grades by the students and the other citizens ( 4 and 5), the teachers themselves were more critical of their work (the dominant grade was 3), which can in part be explained by their insufficient preparation for this type of education (see Allen et al., 2017). Some of them were forced to, over a very short period of time, learn how to use the most modern educational technology for distance education, to use tools to design educational material (Word, Excel, PowerPoint), and to under inadequate circumstances (problems regarding the availability of technology) prepare educational material which was electronically sent to their students. In addition, in some cases there was a lack of support from the educational environment, and the teachers were often, due to an increased workload and problems pertaining to the preparation of educational material, exposed to stress (Ballova Mikuškova \& Verešova, 2020; Lautenbach \& Randell, 2020; Wilson \& Christopher, 2008). This was also confirmed by the research results of the Institute for the Improvement of Education of the Republic of Serbia. Namely, education workers have indicated that their main problems when realizing distance education were the following: the availability of resources and technology to the students $(52.3 \%)$ and the teachers (37.4\%), increased workload and stress during work from home (51.6\%), evaluations of the progress made by the students $(41.5 \%)$, as well as the low level of digital competences of the students (33.5\%) and the teachers (25.3\%) (Institute for the Improvement of Education of the Republic of Serbia, 2020). In that respect, it is very important to provide the conditions needed to acquire the necessary competences on the part of the teachers, so that they could adequately be involved in the process of planning, shaping, realizing and evaluating distance education at various levels of education, and in various institutions. Thus, the teachers can be prepared to face the challenges of distance education and to perform their professional role without burden or stress. 
Suzana V. MARKOVIĆ KRSTIĆ, Lela R. MILOŠEVIĆ RADULOVIĆ. Evaluating distance education in Serbia during the Covid-19 pandemic

PROBLEMS

OF EDUCATION

IN THE $21^{\text {st }}$ CENTURY Vol. 79, No. 3, 2021

480

It is difficult to measure the quality of distance education, as it depends on the motivation of the students and their abilities on the one hand, and their family living conditions, socioeconomic status, health situation and the like, on the other. During the pandemic, schools are facing serious challenges - to choose whether to organize distance education, even though it is clear that a great many students do not have access to the internet and that they will be excluded from the teaching process, or whether not to organize it, which can lead to all the students missing out on their education (Lee \& Lubienski, 2017). However, limited access to the internet is only one of the obstacles. There is also the problem of the parents. Many parents, due to their type of work, do not have enough time to work with their children, and many are not technologically proficient enough to help their children manage the digital platforms. This makes following along in class for children from families of a lower socio-economic status, and with lower cultural and educational capital, more difficult (OECD, 2020). The results of a study carried out in Montenegro by IPSOS, with the support of the British Embassy Podgorica and UNICEF Montenegro (on a sample of 1037 parents or guardians of school age children) have indicated that the parents of school age children take a negative view of distance education (an attitude shared by almost $3 / 5$ of the surveyed parents). However, in addition to the problems which refer to motivation, work habits, unobjective grading, not being in contact with their peers, and a low socio-economic status (especially in the case of children from the Roma population), most parents have given a positive evaluation of the dedication of the teachers and the organization of work in accordance with the new circumstances (A parent-based study of education during the COVID-19 pandemic, 2020, p. 19). Transitioning to the digital world of learning and education leads to an even greater manifestation of social inequality in education, from children who rely on the school to provide them with food and a safe environment, to the digital divide in which children have no suitable devices and internet connections and are unable to follow along in class and learn (Barrett, 2020).

The advantages and disadvantages noted during distance education, which were indicated by the research results, can be used to further develop the theoretical-methodological approaches used to analyze distance education. On the other hand, they can contribute to the potential association between the research results and the practical solutions for tasks which emerged during this sort of education, that is, for defining new directions and recommendations for the organization of this type of work in education. A positive impact of distance education and distance learning on education during the pandemic is based on the possibilities which distance learning offers. They are reflected in the greater flexibility in the approach of the students and the teachers (they are not limited by time and space during the learning-teaching process), and the better conditions and resources which are available to them (Cejas Martinez et al., 2021). Even though distance education does not bring into question the pedagogical aspect of work, it leads to changes in the overall educational experience both in the case of the learning-teaching process, and the means by which this process is realized (Dhurumraj et al., 2020; Larsen \& Vinsent-Lankrin, 2006; Mnguni \& Mokiwa, 2020).

\section{Conclusions and Implications}

The question of the quality of distance education in the context of the pandemic caused by the corona virus is very current and important, since the quality of the education process carried out in various modalities depends on the intellectual and moral development of young individuals. During the pandemic, in addition to acquiring knowledge and developing abilities and skills, more and more importance is being assigned to enabling young people to face various challenges, from preserving their health to using new technologies as part of the learningteaching process. That is why the questions which refer to the possibility of the potential development of abilities and skills needed by students is becoming increasingly current, both 
for life in a state of emergency, and for life after the end of the pandemic in a world which is

constantly changing (adaptability, quick decision-making, creative problem-solving skills).

The educational institutions in Serbia responded to the challenges of the pandemic by adapting to the situation and offering various modalities of distance education. Namely, after the state of emergency was declared in Serbia, and the classic means of education in schools at universities was cancelled, distance learning classes were organized very quickly. That is how learners and students, facing the difficulties associated with a state of emergency continued to learn, without interruption, as part of the realization of the curriculum.

The research results confirmed the initial hypotheses on the predominance of high positive grades awarded to the quality of certain modalities of distance education and the existence of statistically significant differences in the evaluation of quality, based on whether they were made by the teachers, the students, or the other citizens of Serbia. However, the highest grades were awarded to online education taking place on the Google Classroom, Google Meet, Zoom platforms.

Bearing in mind the experiences and the results achieved through distance education in Serbia during the pandemic, it can be expected that such a form of education will be increasingly more present in regular academic practice in the future, as it has significant advantages compared to classic forms of education (for example, flexibility in terms of work, as the students and teachers can determine the place, time, and tempo of the learning themselves). This increases the effectiveness of education, encourages creativity on the part of the students, and over a short period of time educates a great many of them, without the involvement of more teachers or the use of more space. In that sense, this type of education is considerably cheaper than the classic, traditional kind.

Organizing distance education in Serbia during the COVID-19 pandemic confirmed the importance of the implementation of modern technologies in the realization of the curriculum and indicated the advantages and disadvantages of this kind of work. Accordingly, new possibilities opened up for a future intense development of these technologies and their implementation in the learning-teaching process. With the aim of overcoming the noted disadvantages of distance education, further comparative qualitative and quantitative studies on a larger sample, and in more countries, are needed. Special emphasis should be placed on the issue of the motivation of teachers and students for this kind of education, the problem of evaluating students, as well as the problem of social inequality as it pertains to distance education. We can expect that social inequality in education to be more pronounced over time due to the economic crisis caused by the pandemic (loss of work or pay cuts).

With the aim of developing distance education in Serbia, it is necessary to introduce changes to the legal regulations and enable the rapid development of information-communication technologies. In that sense, the initial assumptions pertaining to the development of the educational system, and especially distance education, include the low cost of technical equipment, the increase in internet speed, a greater choice of software for communication, as well as the further education of teachers and students which would enable them to develop their digital competences for work and learning, and would also provide them with key skills and abilities needed for life and work in the $21^{\text {st }}$ century. Using a greater number of available free platforms enabled the quick and effective organization of educational content and distance education during the pandemic, and confirmed the importance of the development and implementation of this type of education in the future. The state, the authorities, the relevant institutions, and the teachers can all contribute to and support the development of distance education by continuing the activities begun during the pandemic, and by creating favorable social conditions for the improvement and modernization of distance education. 
Suzana V. MARKOVIĆ KRSTIĆ, Lela R. MILOŠEVIĆ RADULOVIĆ. Evaluating distance education in Serbia during the Covid-19 pandemic

PROBLEMS

OF EDUCATION IN THE $21^{\text {st }}$ CENTURY Vol. 79, No. 3, 2021

482

\section{Notes}

1. "The Official Gazette of the Republic of Serbia", 30/2020; Decision on suspension of teaching in higher education institutions and secondary and primary schools, and regular work of institutions for pre-school education ("The Official Gazette of the Republic of Serbia", 29/2020) and the Decree on the measures of the state of emergency ("The Official Gazette of the Republic of Serbia", 31/2020).

2. September 1, 2020 marks the beginning of the implementation of the Rulebook on the requirements for achieving quality and the manner of quality assurance and evaluation of distance learning in primary schools (Article 4) (https://www.paragraf.rs/propisi/pravilnik-uslovikvalitet-nastave-na-daljinu-za-osnovne-skole.html).

3. The authors were members of the research team.

4. The research results mostly refer to students, since there are few adult secondary school students who filled out the survey questionnaire.

5. The difference in the number of respondents in relation to the overall sample can in part be explained by the fact that some of the respondents believed themselves not to be sufficiently well-informed regarding how the learning-teaching process was carried out online (depending on their level of education and occupation), so they did not provide an evaluation of the quality of online education (Google Classroom, Google Meet, Zoom).

\section{Declaration of Interest}

Authors declare no competing interest.

\section{References}

Allen, J., Sinclair, M., \& Smith, R. (2017). Using Mead's theory of emergence as a framework for sociological inquiry into pre-service teacher education. Sociological Research Online, 14(5), 14-26. https://journals.sagepub.com/doi/10.5153/sro.1948 -

Barrett, S. (2020). Coronavirus on campus: College students scramble to solve food insecurity and housing challenges. CNBC. https://www.cnbc.com/2020/03/23/coronaviruson-campus-studentsface-food-insecurity-housing-crunch.html

Beck, U. (1992). Risk Society: Towards a New Modernity. Sage.

Ballova Mikuškova, E., \& Verešova, M. (2020). Distance education during Covid-19: The perspective of Slovak teachers. Problems of Education in the 21st Century, 78(6), 884-906. https://doi.org/10.33225/pec/20.78.884

Cejas Martinez, M. F., Navarro Cejas, M., Venegas Alvarez, G. S., Proano Rodriguez, C. E., \& Mendoza Velazco, D. J. (2021). Student perceptions of Ecuadorian virtual platforms during the Covid-19 pandemic. Problems of Education in the 21st Century, 79(2), 241 254. https://doi.org/10.33225/pec/21.79.241

Ćamilović, D. (2012). Distance Education Trends. Globalisation challenges and the social-economic environment of the EU (pp. 125-132). https://fei.uni-nm.si/uploads/_custom/01_unmfei/ konferenca/zbornik/unm_fei_fpuv_zbornik_prispevkov_konferenca_2012.pdf\#page $=125$

Defining quality in education (2000). UNICEF. https://pdf4pro.com/view/defining-quality-in-educationhome-page-unicef-aefce.html

Dhurumraj, T., Ramaila, S., Raban, F., \& Ashruf, A. (2020). Broadening educational pathways to STEM education through online teaching and learning during Covid-19: Teachers' perspectives. Journal of Baltic Science Education, 19(6A), 1055-1067. https://doi.org/10.33225/jbse/20.19.1055 
Suzana V. MARKOVIĆ KRSTIĆ, Lela R. MILOŠEVIĆ RADULOVIĆ. Evaluating distance education in Serbia during the Covid-19 pandemic

Gidens, E. (2003). Sociologija [Sociology]. Ekonomski fakultet.

Held, D., McGrew, A., Goldblatt, D., \& Perraton, J. (Eds.) (1999). Global transformations: Politics, IN THE $21{ }^{\text {st }}$ CENTURY Vol. 79, No. 3, 2021 economics and culture. Stanford University Press.

Held, D., \& McGrew, A. (2002). Globalization and anti-globalization. Polity.

Istraživanje s roditeljima o školi tokom pandemije COVID-19 (2020). [A parent-based study of education during the COVID-19 pandemic]. https:/www.unicef.org/montenegro/media/15881/file/mnemedia-1000.publication.pdf

King, F. B., Young, M. F., Drivere-Richmond, K., \& Schrader, P. G. (2001). Defining distance learning and distance education. AACE Journal, 9(1), 1-14.

Kung-Ming, T., \& Khoon-Seng, S. (2009). Asynchronous vs. synchronous interaction. Encyclopedia of Distance Learning ( $2^{\text {nd }} E d$.). Information Science Reference (pp. 122-132). IGI Global. https:/www.igi-global.com/chapter/asynchronous-synchronous-interaction/11746

Larsen, K., \& Vincent-Lancrin, S. (2006). The impact of ICT on tertiary education: Advances and promises. In: Kahin, B., Foray, D. (Eds.) Advancing knowledge and the knowledge economy (pp. 151-168). MIT Press.

Lautenbach, G., \& Randell, N. (2020). Through the Covid-19 looking glass: Coping skills for STEM educators in the time of a pandemic and beyond. Journal of Baltic Science Education, 19(6A), 1068-1077. https://doi.org/10.33225/jbse/20.19.1068

Lee, J., \& Lubienski, C. (2017). The impact of school closures on equity of access in Chicago. Education and Urban Society, 49(1), 53-80. https://doi.org/10.1177/0013124516630601

Marković, Ž. D. (2008). Globalizacija i visokoškolsko obrazovanje [Globalization and higher education]. Državni univerzitet Novi Pazar i Univerzitet u Nišu.

Mnguni, L., \& Mokiwa, H. (2020). The integration of online teaching and learning in STEM education as a response to the Covid-19 pandemic. Journal of Baltic Science Education, 19(6A), 1040-1042. https://doi.org/10.33225/jbse/20.19.1040

OECD (2020). Tackling coronavirus (COVID-19). http://www.oecd.org/coronavirus/en/

Orellana, A., Hudgins, T., \& Simonson, M. (2009). The perfect online course: Best practices for designing and teaching. IAP-Information Age Publishing.

Pravilnik o bližim uslovima za ostvarivanje i način osiguranja kvaliteta i vrednovanje nastave na daljinu u osnovnoj školi (2020). [The Rulebook on the requirements for achieving quality and the manner of quality assurance and evaluation of distance learning in primary schools]. The Official Gazette of the Republic of Serbia, 109/2020. https://www.paragraf.rs/propisi/pravilnik-uslovi-kvalitetnastave-na-daljinu-za-osnovne-skole.html

School Education Gateway (2020). Survey on online and distance learning - Results. Europe's online platform for school education. https:/www.schooleducationgateway.eu/en/pub/viewpoints/ surveys/survey-on-online-teaching.htm

Stepanović, S. (2020). Uticaj pandemije virusa korona na obrazovanje [The impact of the pandemic caused by the corona virus on education]. Nastava $i$ vaspitanje, 69(2), $183-$ 196, https://doi.org/10.5937/nasvas2002183S

Stepanović, S. (2018). Inkluzija [Inclusion in education]. Sumatra.

Stojanović, D. (2020). Analiza realizacije učenja na daljinu u Srbiji za vreme pandemije virusa Covid-19 [Analyzing how online education was realized in Serbia during the COVID-19 pandemic] (pp. 121-140). http://ebooks.ien.bg.ac.rs/1492/1/7.\%20stojanovic.pdf

The Ministry of Science and Education of the Republic of Croatia (2020). Akcijski plan za provedbu nastave na daljinu (2020) [Action plan for the implementation of the distance education] (pp. $1-38)$.

https://mzo.gov.hr/UserDocsImages/dokumenti/Obrazovanje/NastavaNaDaljinu/Akcijski\%20plan\%20 za\%20provedbu\%20nastave $\% 20$ na $\% 20$ daljinu $\% 20-\% 20$ Model $\% 20$ nastave $\% 20$ na $\% 20$ daljinu. pdf

Wilson, B. G., \& Christopher, L. (2008). Hype versus reality on campus. The e-Learning Handbook (pp. 29-54). Pfeiffer.

Wallerstein, I. (2000). Globalization or the age of transition? A long-term view on the trajectory of the world-system. International Sociology, 15(2), 249-265. 
Suzana V. MARKOVIĆ KRSTIĆ, Lela R. MILOŠEVIĆ RADULOVIĆ. Evaluating distance education in Serbia during the Covid-19 pandemic

PROBLEMS

OF EDUCATION

IN THE $21^{\text {st }}$ CENTURY

Vol. 79, No. 3, 2021

484

ZUOV [Institute for the Improvement of Education of the Republic of Serbia] (2020). Rezultati ankete [Survey Results]. https://zuov.gov.rs/rezultati-ankete-sta-15-000-prosvetnih-radnika-misli-oostvarivanjuobrazovno-vaspitnog-procesa-putem-ucenja-na-daljinu

Received: April 18, 2021

Accepted: June 07, 2021

Cite as: Marković Krstić, S., \& Milošević Radulović, L. (2021). Evaluating distance education in Serbia during the Covid-19 pandemic. Problems of Education in the 21 $1^{\text {st }}$ Century, 79(3), 467-484. https://doi.org/10.33225/pec/21.79.467

Suzana V. Marković Krstić (Corresponding author)
PhD, Associate Professor, University of Niš, Faculty of Philosophy, Department of Sociology, Ćirila i Metodija 2, 18000 Niš, Serbia.

E-mail: suzana.markovic.krstic@filfak.ni.ac.rs

Website: https://www.filfak.ni.ac.rs/nastavno-osoblje/sociologija/item/153suzana-markovic-krstic

ORCID: https://orcid.org/0000-0002-2181-3647

Lela R. Milošević Radulović
$\mathrm{PhD}$, Associate Professor, University of Niš, Faculty of Philosophy, Department of Sociology, Ćirila i Metodija 2, 18000 Niš, Serbia.

E-mail: lela.milosevic.radulovic@filfak.ni.ac.rs

Website: https://www.filfak.ni.ac.rs/nastavno-osoblje/sociologija/item/155lela-milosevic-radulovic

ORCID: https://orcid.org/0000-0003-3226-0432 